\title{
College textbook reading assignments and class time activity
}

\begin{abstract}
Lola Aagaard ${ }^{1}$, Timothy W. Conner II $^{2}$, and Ronald L. Skidmore ${ }^{3}$
Abstract: A convenient cluster sample of 105 undergraduate students at a regional university in the midsouth completed a survey regarding their use of college textbooks, what strategies might increase the likelihood of their reading textbook assignments, and their preference for how class time was used. Descriptive analysis was conducted on the results and chi-square was run on 25 selected comparisons, with a Bonferroni correction of the resulting alphas. About half the students reported that they do read the assigned textbook readings. Freshmen were significantly more likely to report that outside reading should not be required of students prior to coming to class, and less likely to report having used or known about e-textbooks. Strategies reported to most likely prompt reading the textbook included in-class quizzes over text material, assigning graded study-guides to complete while reading; testing over material found in the textbook but not covered in class; and assigning shorter reading assignments. Preferences for use of class time varied by experience in college, but the majority of students preferred group discussion and application of material to real life rather than just lecture over the textbook content.
\end{abstract}

Keywords: Higher Education; College Teaching; Textbook Use; Instructional Strategies

\section{Introduction}

Regardless of the fact that professors often assign textbook readings to students as part of their course requirements, reports have clearly articulated that many students (perhaps most of them), do not actually complete the course readings as instructed (Lei, Barlett, Gorney, \& Herschbach, 2010; Pecorari, Shaw, Irvine, Malstrom, \& Mezek, 2012; Sikorski et al., 2002). This lack of student engagement in reading for the courses not only includes assigned readings for traditional class meetings, but also in terms of preparing for course examinations (Aagaard \& Skidmore, 2004; Clump, Bauer, \& Bradley, 2004; Sikorski et al., 2002). The implications of these findings would seem to suggest that most of what students glean from course study comes directly from the learning experiences conducted within the classroom, with the in-class presentation of material serving as the primary means by which students gain understanding of important course concepts. This model of engagement with courses changes the course pedagogical arrangement, as students who might otherwise benefit from discussion and application of course concepts must instead be introduced to concepts and terminology during class. In other words, students' lack of engagement in independent reading of class assignments compels professors to make a different set of lecture plans when thinking about what to do with students during class.

\footnotetext{
${ }^{1}$ Associate Professor, Morehead State University, Foundational and Graduate Studies in Education, 1.aagaard@moreheadstate.edu

${ }^{2}$ Assistant Professor, Morehead State University, Foundational and Graduate Studies in Education, t.conner@moreheadstate.edu

${ }^{3}$ Professor, Morehead State University, Foundational and Graduate Studies in Education, r.skidmore@moreheadstate.edu
} 
As lack of student reading prior to class time necessarily limits the depth to which professors can engage learners with important course concepts, studies of methods by which to compel students to read the course text and reading materials have been conducted. Suggested strategies that have emerged from such investigations have included quizzes over course materials (Johnson \& Kiviniemi, 2009; Ruscio, 2001; Ryan, 2006), worksheets with which students study (Aagaard \& Skidmore, 2009; Ryan, 2006), chunking the reading tasks into smaller segments, and using the textbook during class instructional activities rather than only asking students to read the materials outside of class (Aagaard \& Skidmore, 2009). The efficacy of each of these strategies will need to be properly explored should instructors in the academy wish to promote independent student engagement in course readings outside of class.

Although we seem to understand the basic nature of college students and the use (or lack thereof) of course texts and other readings outside of the classroom, related questions left somewhat unaddressed deal not only with what professors might do to compel student reading outside of class, but also with what students might prefer professors do with the time they share together learning within the classroom context. That is to say, some great attention has been given to the exploration of student use of reading materials, but has there been sufficient support to understand what professors do with instruction to promote learning from the perspective of students? After all, education should be a dynamic process that involves engagement not only from the perspective of the educators, but also from the students, as is the case with methods such as inquiry learning (Oliver, 2007). The question that remains, however, is not only one of what methods of instruction might be effective when instituted by instructors, but also one of what kind of research has been conducted to ascertain students' preferences with instructional time during class activities at the college level?

As stated above, students have expressed a desire for professors to use a variety of inclass activities to promote their independent reading of course materials, including testing over the textbook readings, shortening the reading assignments, providing advanced organizers to guide note-taking while they read (and offering credit for them), and using the textbooks in class (Aagaard \& Skidmore, 2009). It would seem, as suggested by Aagaard and Skidmore, (2009), and others (Berry, Cook, Hill, \& Stevens, 2011; Johnson \& Kiviniemi, 2009; Oliver, 2007), that undergraduate students are quite dependent on their professors in terms of promoting the independent use of course readings outside of class, -- if the professors require it, give credit for doing it, give specific guidance and direction as to what is relevant and essential, and provide scaffolds to teach students how to do it, then students will probably read on their own outside of class.

This sentiment of dependence on the professor as a model is echoed in the work of M. P. Ryan (2001) whose study of conceptual models of lecture learning and note taking practices revealed that, in most of the models offered, students' metaphors for the role of the instructor during lecture ultimately impacted the ways in which they engage in learning behaviors in class, such as the ways in which and purposes for which they engage in note taking behaviors. An implication from this work would be that, if professors should want more appropriate learning behaviors to be demonstrated by students during class, then they (the professors) should model such behaviors during instruction in ways that promote particular note taking practices appropriate for the subject matter being taught (Ryan, 2001). As indicated by Ryan (2001) "efforts to improve lecture learning may only begin to produce substantial and pervasive benefits for college learners when they focus as much on conceptual change as they do on behavioral change" (p. 307). 
With regard to the use of lecture-based instruction, one factor that should be taken into account when considering students' preferences for professors' teaching strategies in class is the degree to which students endorse particular lecture-based styles (Kane, 1990; Mji \& Kalashe, 1998; Struyven, Dochy, \& Janssens, 2012). For example, when asking students to comment on their preferences concerning the degree to which professors used structured assignments during lecture (such as following lectures with worksheets to complete after each lesson) as opposed to less structured lecture formats, students indicated strongly that they preferred more structure to rather than less during lecture; however, the continual use of only one strategy repeatedly was also reported to be a disadvantage as students perceived a relative loss of autonomy in the classroom (Kane, 1990). In other words, although the students reported that implementing within-class assignments was beneficial, what students really wanted was for the professor to alternate modes of delivery based upon the material being presented (Kane, 1990).

Other than traditional lecture-based formats of instruction, another method found in the literature about student preference and student learning outcomes includes problem-based or inquiry learning (Oliver, 2007; Struyven, Dochy, \& Janssens, 2012). In the case of inquiry learning, Oliver (2007) revealed that, when the course materials were structured around solving authentic problems within the discipline rather than merely lecturing over course concepts and content, more students reported enjoying the method of delivery and over $90 \%$ perceived positive outcomes as a result of this approach. However, students still expressed problems with the inquiry learning approach, including the relevance of the problems offered, its organization (with particular focus on the directions and instructions), and the difficulty of some of the problems (to which the author attributed the lack of clarity in directions) (Oliver, 2007).

Zhang's (2008) work focused upon not only the preferred teaching styles of students, but also the relationship between students' teaching style preferences and their achievement in academic tasks. Although this study utilized boys in secondary school in Hong Kong, it was revealed that the participants' preferences for teachers that promoted creative thinking, collaboration among students and the use of higher-order reasoning in class over monotone, traditional teacher-centered approaches was reflective of those practices favored by university level students as well. Further, this study indicated that, in most areas asked about, students' preferred teacher practices related positively to their academic achievement while traditional and least-favored practices had an adverse relationship with student achievement (Zhang, 2008).

As can be seen, there appears to be a whole host of ways in which classes can be structured to support learning for undergraduate students most in need for guided support from their college professors. However, in addition to considering the learning outcomes or instructor preferences alone, it is critically important that researchers seek to understand the degree to which students' preference for learning contexts plays a role in their ability to achieve academically in the courses being offered (Struyven, Dochy, \& Janssens, 2012; Zhang, 2008). Rather than worry about the amount of content we cover in classes we teach, perhaps professors should consider the notion that teaching less content in ways students endorse might be more advantageous to their students' overall understanding of the course material (Locher, 2004). Perhaps professors should take more time to consider the multitude of ways that the content might be approached in class, offering students variety so that they may be better engaged in the various course topics (Kane, 1990).

These concerns over student engagement with textbooks and classroom activities led to the research questions for this study: What types of professor behaviors encourage students to 
Aagaard, L., Conner II, T.W., \& Skidmore, R.L.

engage with their textbooks? What are students' preferences for learning content in the classroom?

\section{Method}

\section{Participants}

This study employed a convenient cluster sample of 105 students from eight summer classes at a regional university in the mid-south (see Table 1).

Table 1

Frequency of Students Surveyed in Each Course

\begin{tabular}{lll}
\hline Course & $\mathrm{n}$ & $\%$ \\
\hline Soils (Agriculture) & 13 & 12.9 \\
Geology & 9 & 8.6 \\
Philosophy & 8 & 7.6 \\
English & 18 & 17.1 \\
History & 13 & 12.4 \\
Foundations (Education) & 10 & 9.5 \\
Biology & 16 & 15.2 \\
\hline
\end{tabular}

Approximately $36 \%$ of the students were in natural science courses and $64 \%$ were in humanities or education courses.

Sixty-one percent of respondents were female and nearly $100 \%$ were Caucasian. They reported 29 different majors, with the highest concentrations being education (17\%), biologyrelated (13\%), and agriculture-related (10\%). The 101 students who reported majors could be classified into two basic categories of science/technology/math $(n=43)$ and humanities/social science/business/education $(n=58)$. The distribution across year in college is shown in Table 2 .

Table 2

Sample Distribution Across Year in College

\begin{tabular}{lll}
\hline Year & $\mathrm{n}$ & $\%$ \\
\hline Freshman & 26 & 25 \\
Sophomore & 19 & 18 \\
Junior & 26 & 25 \\
Senior & 33 & 31 \\
Graduate & 1 & 1 \\
\hline
\end{tabular}

Students were asked to self-report their GPA range. A large majority (63\%) claimed a B average, while $30 \%$ reported a $\mathrm{C}$ average. The remaining $7 \%$ were split between $\mathrm{A}$ and $\mathrm{D}$ average grade point averages. 


\section{Instrumentation}

Participants were administered a 25-item researcher-designed survey (see Appendix A) that included 11 items regarding use of course textbooks, 11 items about preferences for use of class time, and four demographic items. All items were multiple-choice.

Textbook items asked whether students read their textbooks when assigned to do so, as well as whether particular strategies by the professor would get students to read their textbooks or not. Each class time use preference item was forced choice between two options (for instance, between professor lecture and group activities).

\section{Procedure}

Researchers requested permission from course instructors to administer the survey to their students in the last 15 minutes of a regularly scheduled class period.

\section{Analysis}

Frequency analyses were performed on every item for descriptive purposes and cross-tabulations were created of every item with each of three of the demographic variables. The cross-tabs were visually inspected and chi-square analyses were run on 25 selected comparisons, with a Bonferroni correction of the resulting alphas. As a result, chi-square tests with p-values of less than or equal to 0.002 were considered significant. As a follow-up analysis, cross-tabulations were created of every item with the two broad categories of student majors. Only one of the items showed a frequency difference of more than $10 \%$ between the responses of the majors and a chi-square analysis was run on that item.

\section{Results}

\section{Textbook Use}

A majority of students (52\%) reported that they do read the assigned textbook readings, but $48 \%$ replied that whether or not they read the assignment depended on other factors. Freshmen were significantly more likely to report that reading the textbook before class should not be required, while seniors were more likely to say that whether they should have to read the text depended on other things (see Table 3).

Table 3

Chi-square Analysis of Year in College by "Should be Required to Read Text?"

\begin{tabular}{lllll}
\hline & Freshman & Sophomore & Junior & Senior/Grad \\
\cline { 2 - 5 } Item Response & $\mathrm{n}($ row $\%)$ & $\mathrm{n}($ row $\%)$ & $\mathrm{n}($ row $\%)$ & $\mathrm{n}($ row \%) \\
\hline Yes & $5(16)$ & $11(34)$ & $8(25)$ & $8(25)$ \\
No & $13(62)$ & $1(5)$ & $5(24)$ & $2(9)$ \\
It Depends & $8(15)$ & $7(13)$ & $13(25)$ & $24(46)$ \\
\hline
\end{tabular}

Note: Chi-square $=28.98 ; \mathrm{df}=6 ; \mathrm{p}<0.0001$ 
Aagaard, L., Conner II, T.W., \& Skidmore, R.L.

Freshmen were significantly less likely to report having used or known about e-textbooks (see Table 4).

Table 4

Chi-square Analysis of Year in College by "Ever Used an e-Text?"

\begin{tabular}{lllll}
\hline & Freshman & Sophomore & Junior & Senior/Grad \\
\cline { 2 - 5 } Item Response & $\mathrm{n}($ row $\%)$ & $\mathrm{n}($ row $\%)$ & $\mathrm{n}($ row $\%)$ & $\mathrm{n}($ row \%) \\
\hline Yes & $1(4)$ & $8(32)$ & $9(36)$ & $7(28)$ \\
No & $11(21)$ & $6(11)$ & $14(26)$ & $22(42)$ \\
It Depends & $14(56)$ & $5(20)$ & $3(12)$ & $3(12)$ \\
\hline
\end{tabular}

Note: Chi-square $=26.02 ; \mathrm{df}=6 ; \mathrm{p}<0.0002$

Strategies reported to most likely prompt reading the textbook included in-class quizzes over text material, assigning graded study-guides to complete while reading; testing over material found in the textbook but not covered in class; and assigning shorter reading assignments (see Table 5).

Table 5

Response to Suggested Strategies to Get Students to Read Textbooks

\begin{tabular}{llll}
\hline & Not Read & Might Read & Most Likely Read \\
\cline { 2 - 4 } Strategy & $\mathrm{n}($ row \%) & $\mathrm{n}($ row \%) & $\mathrm{n}($ row \%) \\
\hline In-class quiz & $0(0)$ & $28(27)$ & $76(73)$ \\
Online open-book quiz & $20(19)$ & $35(34)$ & $49(47)$ \\
Study guide for credit & $4(4)$ & $20(19)$ & $81(77)$ \\
Discuss in class & $14(14)$ & $39(38)$ & $50(48)$ \\
Test material not discussed & $5(5)$ & $14(14)$ & $84(81)$ \\
Shorter reading & $1(1)$ & $23(22)$ & $79(77)$ \\
assignments & & $39(37)$ & $30(29)$ \\
Explain instructional & $35(34)$ & & \\
features of textbook & & & \\
\hline
\end{tabular}

The lowest rated strategy was having the use of the textbook's instructional features (glossary, chapter summaries, etc.) explained to students.

Females were significantly more likely than males to read the textbook if there were going to be in-class quizzes, as reported in Table 6 . 
Aagaard, L., Conner II, T.W., \& Skidmore, R.L.

Table 6

Chi-square Analysis of Male and Female Responses to "Read Text if there is an In-Class Quiz?"

\begin{tabular}{lll}
\hline & Male & Female \\
\cline { 2 - 3 } Item Response & $\mathrm{n}($ row $\%)$ & $\mathrm{n}($ row $\%)$ \\
\hline Might Read & $19(68)$ & $9(32)$ \\
Would Read & $22(29)$ & $54(71)$ \\
\hline
\end{tabular}

Note: Chi-square $=12.97 ; \mathrm{df}=1 ; \mathrm{p}<0.0003$

\section{Preference for Use of Class Time}

Students reported preferring the use of PowerPoint lectures to notes on the chalkboard and generally preferred the use of group discussion and application of material to real-life rather than just lecture over textbook content. They were in favor of group presentations in contrast to individual presentations, but there was more division over in-class group activities, with quite a number choosing the other alternatives when they were presented (see Tables 7 and 8).

Table 7

\section{Preferences for Use of Class Time (Lecture-Related)}

\begin{tabular}{lll}
\hline I would prefer the professor: & $\mathrm{n}$ & $\%$ \\
\hline Lectured only over material that was in the textbook. & 19 & 18 \\
Lectured over the textbook, but also some material that was NOT in the textbook. & 84 & 81 \\
Both choices marked & 1 & 1 \\
\hline & & \\
Have PowerPoint slides to present basic notes for the lecture. & 74 & 71 \\
Use the chalkboard to present basic notes for the lecture. & 25 & 24 \\
Both choices marked & 5 & 5 \\
\hline & & \\
Lectured only over material that will be tested. & 45 & 43 \\
Lectured over tested material, but also over some material that is interesting but not \\
going to be tested.
\end{tabular}

$\begin{array}{lll}\text { Lectured only over the textbook material. } & 7 & 7\end{array}$

Covered the content; gave examples of how the material applied to real life. $\quad 9692$

Both choices marked

1

$\begin{array}{lll}\text { Just lectured over the textbook material in some way. } & 27 & 26\end{array}$

$\begin{array}{lll}\text { Encouraged group discussion of the material. } & 75 & 72\end{array}$

\begin{tabular}{ll} 
Both choices marked & 2 \\
\hline
\end{tabular}

$\begin{array}{lll}\text { Just lectured over the textbook material in some way. } & 43 & 41\end{array}$

$\begin{array}{lll}\text { Had students do group activities related to the material. } & 60 & 58\end{array}$

Both choices marked

$1 \quad 1$

$\begin{array}{lll}\text { Lectured over content in class. } & 73 & 69\end{array}$

$\begin{array}{lll}\text { Put the lectures podcasts online; did other things related to content during class. } & 28 & 27\end{array}$

Both choices marked

$4 \quad 4$

Journal of the Scholarship of Teaching and Learning, Vol. 14, No. 3, August 2014. josotl.indiana.edu 
Aagaard, L., Conner II, T.W., \& Skidmore, R.L.

Table 8

Preferences for Use of Class Time (Not Lecture-Related)

\begin{tabular}{lll}
\hline I would prefer the professor: & $\mathrm{n}$ & $\%$ \\
\hline Encouraged group discussion of the textbook material. & 46 & 45 \\
Had students do in-class group activities related to the textbook material. & 54 & 53 \\
Both choices marked & 2 & 2 \\
\hline & & \\
Had students do in-class group activities related to the textbook material. & 76 & 72 \\
Had students do individual presentations of projects related to the text material. & 28 & 27 \\
Both choices marked & 1 & 1 \\
\hline & & \\
Had students do individual presentations of projects related to the text material. & 36 & 35 \\
Had students do group presentations of projects related to the textbook material. & 66 & 64 \\
Both choices marked & 1 & 1 \\
\hline & & \\
Gave in-class closed-book quizzes over textbook content. & 36 & 35 \\
Gave online open-book quizzes over textbook content prior to the class period. & 68 & 65 \\
\hline
\end{tabular}

Although $64 \%$ of respondents overall preferred group presentations, there was a significant relationship of this preference with year in college. Sophomores and seniors were more likely than expected to opt for individual work, while freshmen and juniors were more likely to prefer group presentations (see Table 9).

Table 9

Chi-square Analysis of Preference for Group vs. Individual Presentations by Year in College

\begin{tabular}{lllll}
\hline & Freshman & Sophomore & Junior & Senior/Grad \\
\cline { 2 - 5 } Item Response & $\mathrm{n}($ row $\%)$ & n (row $\%)$ & n (row $\%)$ & n (row \%) \\
\hline Individual & $6(17)$ & $11(31)$ & $3(8)$ & $16(44)$ \\
Group & $20(30)$ & $8(12)$ & $22(33)$ & $22(24)$ \\
\hline
\end{tabular}

Note: Chi-square $=14.92 ; \mathrm{df}=3 ; \mathrm{p}<0.0019$

For the follow-up analysis by category of major, the only item where student responses showed much difference dealt with whether they believed they should be required to read the textbook prior to coming to class. As shown in Table 10, students who were not in science, technology, or math majors were more likely to answer "It depends" to this question. Because this analysis was a follow-up of the main research questions, it was not subjected to the Bonferroni adjustment of alpha and thus was statistically significant at $\mathrm{p}<0.05$.

\section{Discussion}

The purpose of this study was to ascertain how students at this institution use textbooks assigned for their respective classes, as well as the reactions and preferences that they have regarding instructor-directed presentation methods and other activities. Results of this investigation indicate substantial variation in how text materials are used and preferences for what takes place 
Aagaard, L., Conner II, T.W., \& Skidmore, R.L.

Table 10

Chi-square Analysis of Category of College Major by "Should be Required to Read Text?"

\begin{tabular}{lll}
\hline & Science/Technology/Math & $\begin{array}{l}\text { Humanities/Education/ } \\
\text { Business/Social Science }\end{array}$ \\
\cline { 2 - 3 } Item Response & $\mathrm{n}($ row \%) & $\mathrm{n}($ row \%) \\
\hline Yes & $16(53)$ & $14(47)$ \\
No & $11(58)$ & $8(42)$ \\
It Depends & $16(31)$ & $36(69)$ \\
\hline
\end{tabular}

Note: Chi-square $=6.21 ; \mathrm{df}=2 ; \mathrm{p}<0.045$

during class time. Whether students read text materials seems dependent upon other factors, and not just simply whether the materials are assigned by the instructor (e.g., Table 5). Typically, students indicated that they would read the text materials if there were some associated 'for credit' activity, if the text was used during class time, and if the size of reading assignments was "shorter." Interestingly, first-year (i.e., freshmen) students felt that reading assigned text materials before class time should not be required, with seniors acknowledging that reading the text materials depends upon "other" factors. We speculate that these perspectives and attitudes are the result of their prior academic experiences. College freshmen likely utilize the same techniques during their post-secondary experiences. For example, due to economic reasons, text materials may only be available to students for review during a given class period during their secondary school experience. Concrete presentation and the opportunity for the development of effective independent learning strategies necessary for life-long learning are not likely promoted or practiced. College seniors, however, have likely 'learned the ropes' with respect to the general requirements and expectations of post-secondary experiences, and are able to adjust and adapt their behaviors accordingly.

It would seem that students prefer a "structured with variation" model when it comes to the use of class time. Participants preferred a lecture format, but with related and authentic nontext material / content included. In addition, the preference was expressed for in-class group discussion of the text and other materials as well as for prepared organizers (i.e., PowerPoint slides). Not surprisingly, online open-book quizzes were preferred to in-class closed-book quizzes, yet respondents indicated that they would read the textbook more frequently if quizzes were given in-class in contrast to online. Freshmen and juniors would prefer a group presentation format if this were a component of a course. This might be due to a preference for "safety-innumbers" (i.e., preservation of self-esteem) in open-forum evaluative situations. Interestingly, and somewhat surprisingly, sophomores and seniors preferred to work independently. Perhaps they have been frustrated with prior group projects / presentation experiences where one's evaluation is at least partially determined by the cooperative participation of others (i.e., "once bitten, twice shy"). Senior students may be focused upon finishing course work necessary for attainment of the degree, and therefore are reluctant to expend the socio-emotional time and effort necessary to engage in effective group activities.

The responses of the students participating in this study give indications to instructors regarding how to encourage student reading of the textbook prior to its discussion during a class period. If the top-rated strategies were combined it would mean that students would be given a short reading assignment with a study guide to complete (for credit) during their reading. Then,

Journal of the Scholarship of Teaching and Learning, Vol. 14, No. 3, August 2014. 
after an in-class quiz over the reading assignment, the instructor would have students use the textbook in some way during the class period. When it came time for the unit test, students also would be responsible for material that was in the textbook but not discussed in class.

\section{Limitations of Study}

Although the results offer much for any post-secondary educator to consider, limitations to this particular study emerge with respect to sampling techniques, time of acquisition of data, and weaknesses in understanding differences across students in particular fields. Cluster sampling techniques were used to collect data primarily out of necessity. Perhaps if the study is replicated, researchers could randomly select students within disciplines.

Secondly, the survey was administered to students during a four-week summer term. The number of participants would have been higher if the survey had been administered during a typical sixteen-week academic term. An increase in student participation rates might offer results that are different from the findings of this study. It is also possible that there is something different about students who take classes in the summer terms, so these results may not apply equally to students who never participate in summer school.

Additionally, the distribution of student majors in this study's sample was not sufficient for any meaningful comparisons of students' preferences of textbook reading and class activity across different programs of study. Future researchers in this area may want to intentionally administer surveys to students in particular fields of study to allow for analysis of differences across student majors. A more nuanced analysis like this might reveal differences in preferences between major programs, particularly if the results show consistencies in majors across multiple colleges/universities.

Finally, it should be noted that the instrument used for this study was researcher-created. In future replication of this work, researchers would be advised to not only establish the validity of the items in the current instrument (see appendix), but also to include additional items that relate to other proximal and / or personal / dispositional factors that may also influence students' use of textbooks and their preferences for various classroom strategies.

\section{Appendix}

\section{Appendix A}

Textbook and Use of Class Time Survey

(With overall survey results included as percentages and significance notes where appropriate.)

\section{Do you think you should be required to read material in the textbook before coming to} class?

$\begin{array}{llc}\text { Yes } & \text { No } & \text { It depends } \\ 30 \% & 20 \% & 50 \%\end{array}$

***Signif. Chi-square for year in school $(\mathrm{p}=0.0001)$ : Freshmen more likely to say no; sophomores more likely to say yes; seniors more likely to think it depends. 


\section{Do you actually read the textbook material when it is assigned?

$\begin{array}{llc}\text { Yes } & \text { No } & \text { It depends } \\ 52 \% & 6 \% & 48 \%\end{array}$

3. What could the professor do to get you to read the textbook assignments? (Mark the most appropriate column for each strategy.)

\begin{tabular}{|c|c|c|c|}
\hline Professor's strategy & $\begin{array}{l}\text { I would still } \\
\text { not read the } \\
\text { textbook. }\end{array}$ & $\begin{array}{l}\text { I might read } \\
\text { the textbook. }\end{array}$ & $\begin{array}{l}\text { I would most } \\
\text { likely read the } \\
\text { textbook. }\end{array}$ \\
\hline $\begin{array}{l}\text { a. Give me an in-class quiz over material from the textbook } \\
\text { assignment. } \\
* * * \text { sig. chi-square for gender*** } \mathrm{p}=.0003\end{array}$ & $0 \%$ & $\begin{array}{l}27 \% \\
\text { M: } 46 \% \\
\text { F: } 14 \%\end{array}$ & $\begin{array}{l}73 \% \\
\text { M: } 54 \% \\
\text { F: } 86 \%\end{array}$ \\
\hline $\begin{array}{l}\text { b. Give me an online open-book quiz over the textbook } \\
\text { assignment. }\end{array}$ & $19 \%$ & $34 \%$ & $47 \%$ \\
\hline $\begin{array}{l}\text { c. Have a study guide for me to fill out while reading the } \\
\text { assignment, then give me credit for turning it in. }\end{array}$ & $4 \%$ & $19 \%$ & $77 \%$ \\
\hline $\begin{array}{l}\text { d. Actually discuss the content of the textbook assignment in } \\
\text { class. }\end{array}$ & $14 \%$ & $38 \%$ & $48 \%$ \\
\hline $\begin{array}{l}\text { e. Test me over material that was in the textbook but not } \\
\text { discussed in class. }\end{array}$ & $5 \%$ & $14 \%$ & $81 \%$ \\
\hline f. Make shorter reading assignments. & $1 \%$ & $22 \%$ & $77 \%$ \\
\hline g. Use the textbook in class in some way. & $5 \%$ & $43 \%$ & $52 \%$ \\
\hline $\begin{array}{l}\text { h. Teach me how to use the textbook's instructional features } \\
\text { (glossary, summaries, etc.). }\end{array}$ & $34 \%$ & $37 \%$ & $29 \%$ \\
\hline
\end{tabular}

\section{Have you ever used an e-textbook for one of your classes? \\ Yes No What is an e-textbook?

$24 \% \quad 51 \% \quad 24 \%$

***Signif. Chi-square for year in school $(\mathrm{p}=0.0001)$ : Freshmen less likely to say yes and more likely to say "what is it?"; sophomores more likely to say yes; seniors less likely to say "what is it?"

\section{I would prefer the professor lectured:}

$18 \% \quad$ A. only over material that was in the textbook.

$81 \%$ B. over the textbook, but also some material that was NOT in the textbook.

$1 \% \quad$ (both)

\section{I would prefer the professor used:}

$71 \% \quad$ A. Powerpoint slides to present basic notes for the lecture.

$24 \% \quad$ B. the chalkboard to present basic notes for the lecture.

$5 \% \quad$ (both)

\section{I would prefer the professor lectured:}

$43 \% \quad$ A. only over material that will be tested.

$57 \%$ B. over tested material, but also over some material that is interesting but not going to be tested. 


\section{I would prefer the professor:}

$7 \% \quad$ A. lectured only over the textbook material.

$92 \% \quad$ B. covered the content, but also gave examples of how the material applied to real life.

$1 \% \quad$ (both)

\section{I would prefer the professor:}

$26 \% \quad$ A. just lectured over the textbook material in some way.

$72 \% \quad$ B. encouraged group discussion of the material.

$2 \%$ (both)

\section{I would prefer the professor:}

$41 \% \quad$ A. just lectured over the textbook material in some way.

$58 \%$ B. had students do group activities related to the material.

$1 \%$ (both)

\section{I would prefer the professor:}

$45 \% \quad$ A. encouraged group discussion of the textbook material.

$53 \% \quad$ B. had students do in-class group activities related to the textbook material.

$2 \% \quad$ (both)

\section{I would prefer the professor:}

$72 \% \quad$ A. had students do in-class group activities related to the textbook material.

$27 \%$ B. had students do individual presentations of projects related to the textbook material.

$1 \% \quad$ (both)

\section{I would prefer the professor:}

$35 \%$ A. had students do individual presentations of projects related to the textbook material.

$64 \%$ B. had students do group presentations of projects related to the textbook material.

$1 \% \quad$ (both)

***Signif. Chi-square for year in school (0.0019): Sophomores and seniors more likely to prefer individual presentations; juniors more likely to prefer group presentations.

\section{I would prefer the professor:}

$69 \%$ A. lectured over content in class.

$27 \%$ B. put the lectures in audio files online to be listened to prior to class, then did other interesting things related to the content during class.

4\% (both)

\section{I would prefer the professor gave:}

$35 \%$ A. in-class closed-book quizzes over textbook content.

$65 \%$ B. online open-book quizzes over textbook content prior to the class period.

\section{What is your gender?}
$39 \%$
A. Male
$61 \% \quad$ B. Female 


\section{What year of college are you in?}

$\begin{array}{cl}25 \% & \text { A. Freshman } \\ 18 \% & \text { B. Sophomore } \\ 25 \% & \text { C. Junior } \\ 31 \% & \text { D. Senior } \\ 1 \% & \text { (graduate student) }\end{array}$

\section{What is your overall GPA?}

$\begin{array}{cl}0 \% & \text { A. } 0-0.99 \\ 3 \% & \text { B. } 1.0-1.99 \\ 30 \% & \text { C. } 2.0-2.99 \\ 60 \% & \text { D. } 3.0-3.99 \\ 4 \% & \text { E. } 4.0\end{array}$

\section{References}

Aagaard, L., \& Skidmore, R. (2004, November). Student study habits and the relationship to test scores in an undergraduate course. Paper presented at the annual meeting of the Midsouth Educational Research Association, Gatlinburg, TN.

Aagaard, L., \& Skidmore, R. (2009, November). College student use of textbooks. Paper presented at the annual meeting of the Midsouth Educational Research Association, Baton Rouge, LA.

Berry, T., Cook, L., Hill, N., \& Stevens, K. (2011). An exploratory analysis of textbook usage and study habits: Misperceptions and barriers to success. College Teaching, 59, 31-39. doi: $10.1080 / 87567555.2010 .509376$

Clump, M.A., Bauer, H., \& Bradley, C. (2004). The extent to which psychology students read textbooks: A multiple class analysis of reading across psychology. Journal of Instructional Psychology, 31, 227-232. Retrieved October 16, 2009, from EBSCOhost Academic Search Premier database.

Johnson, B. C., \& Kiviniemi, M. T. (2009). The effect of online chapter quizzes on exam performance in an undergraduate social psychology course. Teaching of Psychology, 36, 33-37. doi: $10.1080 / 00986280802528972$

Kane, B. (1990). Undergraduate students' concerns and preferences regarding structured and unstructured lecture-discussions. Education, 111(1), 117-125. Retrieved October 26, 2010, from EBSCOhost Academic Search Premier database.

Lei, S.A., Bartlett, K.A., Gorney, S.E., \& Herschbach, T.R. (2010). Resistance to reading compliance among college students: Instructors' perspectives. College Student Journal, 44(2), 219-229. Retrieved October 29, 2010, from EBSCOhost Academic Search Premier database. 
Locher, D. (2004). When teaching less is more. The Teaching Professor, 18(9), 2-6. Retrieved October 26, 2010, from EBSCOhost Academic Search Premier database.

Mji, A., \& Kalashe, L. (1998). Exploring the lecturer-student relationship: Preferences of a sample of undergraduate students in business management. Psychological Reports, 83, 1297 1298. doi: 10.2466/PR0.83.7.1297-1298

Oliver, R. (2007). Exploring an inquiry-based learning approach with first-year students in a large undergraduate class. Innovations in Education and Teaching International, 44(1), 3-15. Retrieved October 26, 2010, from EBSCOhost Academic Search Premier database. doi: $10.1080 / 14703290601090317$

Pecorari, D., Shaw, P., Irvine, A., Malstrom, H., \& Mezek, S. (2012). Reading in tertiary education: Undergraduate student practices and attitudes. Quality in Higher Education, 18(2), 235-256. doi: 10.1080/13538322.2012.706464

Ruscio, J. (2001). Administering quizzes at random to increase students' reading. Teaching of Psychoglogy, 28(3), 204-206. Retrieved October, 30, 2010, from EBSCOhost Academic Search Premier database. doi: 10.1207/S15328023TOP2803_08

Ryan, M.P. (2001). Conceptual models of lecture-learning: Guiding metaphors and modelappropriate notetaking practices. Reading Psychology, 22, 289-312. Retrieved October 26, 2010, from EBSCOhost Academic Search Premier database. doi: 10.1080/02702710127638

Ryan, T. E. (2006). Motivating novice students to read their textbooks. Journal of Instructional Psychology, 33(2), 136-140. Retrieved October 30, 2010, from EBSCOhost Academic Search Premier database.

Sikorski, J. F., Rich, K., Saville, B. K., Buskist, W., Drogan, O., \& Davis, S. F. (2002). Student use of introductory texts: Comparative survey findings from two universities. Teaching of Psychology, 29, 312-313. Retrieved October 16, 2009, from EBSCOhost Academic Search Premier database. doi: 10.1207/S15328023TOP2904_13

Struyven, K., Dochy, F., \& Janssens, S. (2012). Explaining student's appraisal of lectures and student-activating teaching: Perceived context and student characteristics. Interactive Learning Environments, 20(5), 391-422. doi: 10.1080/10494820.2010.500084

Zhang, L.F. (2008). Preferences for teaching styles matter in academic achievement: Scientific and practical implications. Educational Psychology, 28(6), 615-625. doi:10.1080/01443410802004634 